\title{
Comparative Study between HI and Indirect ELISA Antibody Titres in Samples for NDV Virus in Poultry
}

\author{
Ojasvita $^{1}$, Himanshu Sharma ${ }^{2}$, Anupama Deora ${ }^{3}$, Sanjay Kapoor ${ }^{2}$, Ajit Singh ${ }^{2}$, \\ Satbir Sharma ${ }^{4 *}$, Mahavir Singh ${ }^{2}$, Pankaj Kumar ${ }^{5}$ and Rajendra Yadav ${ }^{6}$ \\ ${ }^{1}$ Department of Animal Husbandry and Dairying, Haryana, India \\ ${ }^{2}$ Department of Veterinary Microbiology, LUVAS, Hisar, India \\ ${ }^{3}$ Department of Microbiology, COBS, CCSHAU, Hisar, India \\ ${ }^{4}$ Department of Veterinary Surgery, LUVAS, Hisar, India \\ ${ }^{5}$ Disease investigation laboratory, Rohtak, LUVAS, Hisar, India \\ ${ }^{6}$ RVDEC, Mahendergarh, LUVAS, Hisar, India \\ *Corresponding author
}

\section{A B S T R A C T}

Keywords

HI, ELISA, NDV and Sensitivity

Article Info

Accepted:

26 October 2019

Available Online:

10 November 2019
Comparative study between HI and Indirect ELISA antibody titres in samples for NDV Virus in poultry was carried out at Deptt. of Veterinary Microbiology, LUVAS, Hisar. As we all know that Newcastle disease is also known as Ranikhet disease in India. Virus causes a worldwide disease of birds e.g. chickens, turkeys, guinea fowl, pheasants and pigeons. The principal aim of this study is to compare ELISA with HI tests for the diagnosis of Newcastle disease virus (NDV) infections causing respiratory problems in poultry. However, comparative study has been shown that ELISA test is reproducible and have high sensitivity and specificity. Although at present the HI test is most widely used for detecting Abs level in birds. Several poultry producer are using commercial ELISA kit to access post vaccination antibodies level.

\section{Introduction}

Newcastle disease (ND) is one of the most important infectious diseases of poultry. It is distributed worldwide and has the potential to cause large economic losses in the poultry industry (Lancaster, 1976 and Spradbrow, 1988). Its causative agent is Newcastle disease virus (NDV), a virus that is able to infect over 240 species of birds and which spreads primarily through direct contact between infected and healthy birds (Kaleta and Baldauf, 1988).

Based on the severity of the disease, NDV can be grouped into three pathotypes: the 
lentogenic strains caused only clinically mild or inapparent respiratory disease; the mesogenic strains produced respiratory and nervous signs with moderate mortality and the viscerotropic or neurotropic velogenic strain caused severe intestinal lesions or neurological disease, resulting in high mortality even up to $100 \%$ in chicks (Alexander, 1971).

As early, accurate and timely diagnosis is a key to save the left out birds in an organised farm. So, the principal aim of this study is to compare ELISA with HI tests for the diagnosis of Newcastle disease virus (NDV) infections causing respiratory problems in poultry and which test is better in terms of sensitivity and specificity.

\section{Materials and Methods}

All laboratory reagents and solutions were prepared in Milli $\mathrm{Q}^{\circledR}$ ultrapure water/ deionized/distilled water.

Chemicals, biochemicals and molecular biology reagents were of AnalR/LR/molecular biology grade purchased from reputed suppliers/manufacturers.

\section{Virus isolates}

Newcastle disease vaccine (live) lentogenic (La Sota) strain, also known as Ranikhet disease vaccine, $\mathrm{EID}_{50} / \mathrm{DOSE}>10^{6}$, was procured from a commercial supplier. Fifteen tissue samples from suspected field cases were also processed for isolation and detection of NDV.

\section{Blood and sera samples}

Blood samples from chicken vaccinated against NDV were collected and stored at $20^{\circ} \mathrm{C}$. Chicken blood for $\mathrm{HI}$ was taken in Alsever's solution. 25 vaccinated and 10 unvaccinated serum samples were collected from the field.

\section{Virus growth in embryonated eggs}

Embryonated eggs, 9-11 days, old were candled, to mark the position of air sac and an area about $3 \mathrm{~mm}$ below the air sac that was free of blood vessels on the apposite side of the embryo. The egg surface was swabbed with $70 \%$ alcohol and a hole was made $3 \mathrm{~mm}$ below the air sac. With the help of a tuberculin syringe fitted with a 1/2" long 24/26 gauge needle, $0.2-1.0 \mathrm{ml}$ of inoculum (vaccine strain, field sample 1, 2, 4) was deposited into the allantoic cavity. The hole was sealed with melted wax or cello tape. The eggs were placed in the egg incubate at $37^{\circ} \mathrm{C}$ for 4 days. Viability of the embryos was observed daily. For virus harvesting, the eggs were placed overnight in refrigerator; the egg surface swabbed with $70 \%$ alcohol and using sterile forceps, carefully removed the shell and shell membrane and allantoic membrane over the air sac. With the help of a syringe attached to 16 gauge needle, the allantoic fluid was aspirated for HA and HI tests.

\section{Haemagglutination inhibition test (HI)}

\section{Preparation of chicken RBCs}

Blood was collected from at least 2-3 chickens, aged between 2-6 weeks and fully susceptible to NDV, in equal volume of Alsever's solution. The RBCs was centrifuged at $\geq 1200 \mathrm{rpm}$ for 10 minutes and supernatant discarded. The pellet was resuspend in about 25 volumes of NSS, washed 3 times and resuspended the packed RBCs to obtain a final suspension of $1 \%(\mathrm{v} / \mathrm{v})$ in NSS.

\section{HI}

Serial 2-fold dilution of the virus (sample 1, 4, 2 and vaccine) were made in $50 \mu \mathrm{l} /$ well and 
the dilution of the stock virus that would contain 4 HA units of virus was calculated. The dilution of the stock virus that would contain 4 HA units of virus was calculated. The sera samples were heat inactivated in water bath at $56^{\circ} \mathrm{C}$ for 30 minutes. Serial 2fold dilution made of sera by mixing and transferring $50 \mu \mathrm{l}$ in subsequent wells and discarding $50 \mu \mathrm{l}$ from the last well. Then $50 \mu \mathrm{l}$ NDV (1, 4, 2 and vaccine) containing $4 \mathrm{HA}$ units were added to all the wells and lastly added $50 \mu \mathrm{l}$ of $1 \%$ chicken RBCs to all the well. Serum control $(50 \mu \mathrm{l}$ NSS $+50 \mu \mathrm{l}$ serum $+50 \mu \mathrm{l} 1 \%$ RBCs), RBC control (50 $\mu \mathrm{l}$ NSS $+50 \mu 1 \%$ RBCs) and virus controls (50 $\mu \mathrm{l} \mathrm{NSS}+50 \mu \mathrm{l} 4,2,1,0 \mathrm{HA}$ units of virus + $50 \mu 11 \%$ RBCs) was also included. In this way HI titres was performed using 25 vaccinated sera samples, 10 unvaccinated and hyperimmune serum.

Use of NDV La Sota strain (virus vaccine) as Ag in indirect ELISA

Indirect ELISA was performed for detection of $\mathrm{Abs}$ in the 25 vaccinated and 10 unvaccinated serum samples NDV virus as antigen $(\mathrm{Ag})$ was coated in the wells of a 96well microtitre plate. The test conditions were standardized according to the method of Law et al., 1996 and optimized conditions are presented in Table 1.

NDV antigen of 1:20 dilution was prepared in the 'coating buffer' and loaded $100 \mu \mathrm{l} /$ well in different wells in a flat-bottomed 96-wells ELISA plate (NuncMaxisorb®, Denmark) and incubated overnight at $4^{\circ} \mathrm{C}$. After $3 \times 3 \mathrm{~min}$. washings in $200 \mu \mathrm{l} /$ well the 'wash buffer', wells in a flat-bottomed 96-wells ELISA plate were blocked with $3 \%$ BSA in wash buffer and incubated at RT for $1 \mathrm{hr}$. After $3 \times 3 \mathrm{~min}$. washings in $200 \mu \mathrm{l} /$ well the 'wash buffer', test serum samples (1:100) preparations made in the diluent buffer were loaded $100 \mu \mathrm{l} /$ well in different Ag-coated duplicate wells. As negative control, 10 unvaccinated serum sample used and 25 vaccinated serum (1:100) made in the diluent buffer were loaded 100 $\mu \mathrm{l} /$ well in Ag-coated duplicate wells. As positive control, VSI (vaccinated serum samples) serial log 1-5 dilution made in wash buffer and were loaded $100 \mu \mathrm{l} /$ well in Agcoated wells. Hyperimmune sera (serial log 16 dilution) made in wash buffer and were loaded $100 \mu \mathrm{l} /$ well in Ag-coated duplicate wells. For diluent control $100 \mu \mathrm{l} /$ well PBST in duplicate wells. The interaction between Ag and sera samples was allowed for one hour at RT. After $3 \times 3$ min. washings as above, rabbit anti-chicken IgY-HRPO conjugate at 1:5000 dilution in the wash buffer was added 100 $\mu \mathrm{l} /$ well in all wells. Anti-rabbit IgG-HRPO was used for wells coating rabbit anti-NCDV serum dilution and incubated for one hour at RT.

After $4 \times 3$ min. washings in PBST and a $3 \mathrm{~min}$ last washing in the 'substrate reaction buffer', the OPD/H2O2 substrate solution was added $100 \mu \mathrm{l} /$ well and the enzymatic reaction to give yellow coloured end-product was allowed for 5-10 min. The reaction was stopped by adding $50 \mu \mathrm{l} /$ well $4 \mathrm{~N} \mathrm{H} 2 \mathrm{SO} 4$. The yellow solution turned brown and then A492 values in different wells were measured in an ELISA plate reader.

$\log A b$ titre $=\mathrm{X}+[(\mathrm{A}-\mathrm{C}) /(\mathrm{A}-\mathrm{B})] . \mathrm{D}$

Where,

\begin{tabular}{|c|c|}
\hline \multirow{3}{*}{$50 \%$} & $\mathrm{X}=\mathrm{Log}$ of the HN dilution preceeding \\
\hline & A492 value \\
\hline & $\mathrm{A}=\mathrm{A} 492$ value of the $\mathrm{Ab}$ dilution \\
\hline$>50 \%$ & $\begin{aligned} \text { A4492 value }\end{aligned}$ \\
\hline & $\mathrm{B}=\mathrm{A} 492$ value of the $\mathrm{Ab}$ dilution \\
\hline$<50 \%$ & $\mathrm{C}=\begin{array}{c}\mathrm{A} 492 \\
\text { Cut }- \text { off } / 50 \%\end{array}$ \\
\hline & $\mathrm{D}=\mathrm{Log}$ dilution factor \\
\hline
\end{tabular}

$\mathrm{Ab}$ titre of test samples $=[\mathrm{OD}$ of test sample at 1:100/OD of positive control at 1:100] $\times \mathrm{Ab}$ titre of the positive control. 


\section{Results and Discussion}

\section{Newcastle Disease virus}

Newcastle Disease (ND) is highly contagious devastating viral disease affecting most of the avian species of all ages worldwide (Kaleta and Baldauf, 1988). The disease was recorded for the first time in 1926 in Indonesia and in 1928 in India (Sharma and Adalkha, 2009).

In India, the disease is also called Ranikhet disease (RD). Almost 75years and still, ND remains a threat to poultry population and also essentially demands much attention in the present and probably in the the future too. Attempts to control ND have often been inept and unsuccessful (Alexender, 2001).

There have been many vaccines to control ND but none could protect birds from repeated outbreaks. That is why molecular study of the causative pathogen is essential. The present study was done to compare Antibody levels in vaccinated and unvaccinated sera sample by both HI and Indirect ELISA.

Antibody levels in vaccinated and unvaccinated sera samples

\section{HI titres}

HI titres of 25 vaccinated chicken serum samples ranged from 32 to 512 as shown in Table 2 and figure 1. Majority of the samples had HI titre of $256(n=9)$, followed by 128 $(\mathrm{n}=6), 64(\mathrm{n}=4), 512(\mathrm{n}=3)$ and $32(\mathrm{n}=3)$, whereas HI titre in majority of unvaccinated control samples had HI titre of $32(n=7)$, followed by $64(n=22)$ and one unexpectedly high, i.e. 512.

\section{Indirect ELISA}

Results of indirect ELISA are shown in figure 3. In Table 3 are presented A492 values of positive and negative controls along with those of vaccinated chicken sera samples. Cutoff value was found to be 0.188672 and calculated antibody titre of positive control serum sample was 2600. Antibody titres calculated based on positive control titre are shown in table 3 and figure 2 . The antibody titre ranged from 700 to 3833. Comparison of ELISA titre has also been made with HI titre of anti- NDV Abs in vaccinated chicken sera samples in table 4.

\section{Comparison of HI and Indirect ELISA titre in vaccinated and unvaccinated sera samples}

HI titre of 25 vaccinated chicken sera samples ranged from 32-512 but majority had 256 . Unvaccinated control sera also showed titres between 32-64. The presence of low level of HI Antibodies in unvaccinated chicken sera was probably due to the transfer of maternal antibodies via egg yolk into the chicken. One normal serum had unexpectedly very high titre of 512 .

This could have been either due to accidental exposure of bird to NDV or its mixing of vaccinated bird in cages. The HI antibodies levels of $\geq 64$ are considered protective. The majority of vaccinated chicken bird, were having protective levels of Abs in this study.

Although $\mathrm{HI}$ is a simple test to perform, but difficult to standarized. This has been noticed by various investigators (Beard et al., 1985).

An HI titre of 64 is indicative of good protection level. So the titres were below protection level in normal chicken sera samples. Conventionally HI test is used for seromonitoring of vaccinated birds but passive haemagglutination was reported by Roy et al., (2003) as field adaptable and simple alternative to $\mathrm{HI}$ tests. 
Table.1 The standardised ELISA for measuring Ab titre of 25 vaccinated sera sample and 10 negative samples

\begin{tabular}{|c|c|c|c|c|c|}
\hline $\begin{array}{c}\text { Step } \\
\text { no. }\end{array}$ & Steps/reagents & $\begin{array}{c}\text { Diluent/ Buffer } \\
\text { used }\end{array}$ & $\begin{array}{c}\text { Volume/ } \\
\text { Well } \\
(\mu \mathrm{l})\end{array}$ & $\begin{array}{l}\text { Time of } \\
\text { incubation }\end{array}$ & $\begin{array}{l}\text { Incubation } \\
\text { temperature }\end{array}$ \\
\hline 1 & NCDV vaccine Ag coating & $\begin{array}{l}\text { Phosphate buffer } \\
\text { (PB), pH } 7.0\end{array}$ & 100 & $\mathrm{O} / \mathrm{N}$ & $4-8^{\circ} \mathrm{C}$ \\
\hline 2 & Washing & PBST & 200 & $3 \times 3 \mathrm{~min}$. & RT \\
\hline 3 & Blocking & PBST-3\%BSA & 125 & $2 \mathrm{hrs}$. & RT \\
\hline 4 & Washing & PBST & 200 & $3 \times 3 \mathrm{~min}$ & RT \\
\hline 5 & $\begin{array}{l}\text { Antisera, normal sera chicken } \\
\text { Rabbit anti-NCDV serum }\end{array}$ & PBST & 100 & $1 \mathrm{hr}$. & RT \\
\hline 6 & Washing & PBST & 200 & $3 \times 3$ min. & RT \\
\hline 7 & $\begin{array}{c}\text { Anti-chicken IgY- } \\
\text { HRPO/Anti-rabbit IgG HRPO }\end{array}$ & $\begin{array}{l}1: 5000 \text { in PBST } \\
1: 10000 \text { in PBST }\end{array}$ & 100 & $1 \mathrm{hr}$. & RT \\
\hline 8 & Washing & PBST & 200 & $3 \times 3 \mathrm{~min}$ & RT \\
\hline 9 & Washing & $\begin{array}{c}\text { PBST \& Citrate } \\
\text { phosphate } \\
\text { buffer, pH } 5.0(\mathrm{CPB})\end{array}$ & $\begin{array}{l}200 \\
200\end{array}$ & $\begin{array}{l}4 \times 3 \text { min } \\
1 \times 3 \text { min }\end{array}$ & RT \\
\hline 10 & $\begin{array}{c}\text { Substrate/colour development } \\
(\mathrm{OPD} / \mathrm{H} 2 \mathrm{O} 2)\end{array}$ & $\begin{array}{l}\mathrm{OPD}(5 \mathrm{mg} / 10 \mathrm{ml} \\
\mathrm{CPB}) / \mathrm{H} 2 \mathrm{O} 2(2 \mu \mathrm{l})\end{array}$ & 100 & $15 \mathrm{~min}$. & RT \\
\hline 12 & Stop solution & H2SO4 & 50 & - & - \\
\hline
\end{tabular}

Table.2 HI antibody titres in vaccinated and unvaccinated chicken sera samples from the field

\begin{tabular}{|c|c|c|c|c|c|c|c|}
\hline $\begin{array}{c}\text { Serum } \\
\text { Sample ID }\end{array}$ & $\begin{array}{c}\text { HI } \\
\text { titre }\end{array}$ & $\begin{array}{c}\text { Serum } \\
\text { Sample ID }\end{array}$ & $\begin{array}{c}\text { HI } \\
\text { titre }\end{array}$ & $\begin{array}{c}\text { Serum } \\
\text { Sample ID }\end{array}$ & $\begin{array}{c}\text { HI } \\
\text { titre }\end{array}$ & $\begin{array}{c}\text { Serum } \\
\text { Sample ID }\end{array}$ & $\begin{array}{c}\text { HI } \\
\text { titre }\end{array}$ \\
\hline NS1 & 512 & VS1 & 264 & VS11 & 256 & VS21 & 128 \\
\hline NS2 & 64 & VS2 & 256 & VS12 & 64 & VS22 & 32 \\
\hline NS3 & 32 & VS3 & 256 & VS13 & 256 & VS23 & 64 \\
\hline NS4 & 64 & VS4 & 256 & VS14 & 128 & VS24 & 32 \\
\hline NS5 & 32 & VS5 & 512 & VS15 & 128 & VS25 & 32 \\
\hline NS6 & 32 & VS6 & 512 & VS16 & 64 & & \\
\hline NS7 & 32 & VS7 & 256 & VS17 & 256 & & \\
\hline NS8 & 32 & VS8 & 256 & VS18 & 128 & & \\
\hline NS9 & 32 & VS9 & 512 & VS19 & 128 & & \\
\hline NS10 & 32 & VS10 & 256 & VS20 & 128 & & \\
\hline
\end{tabular}


Table.3 A492 values of 25 vaccinated sera samples and 10 unvaccinated samples in indirect ELISA

\begin{tabular}{|c|c|c|c|c|c|c|c|c|c|c|c|c|c|}
\hline & & 1 & 2 & 3 & 4 & 5 & 6 & 7 & 8 & 9 & 10 & 11 & 12 \\
\hline \multirow{6}{*}{ 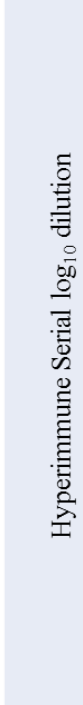 } & A & 2.3452 & 2.2133 & $\begin{array}{c}\mathrm{NS}_{1} \\
0.2492\end{array}$ & 0.2536 & $\begin{array}{c}\mathrm{NS}_{9} \\
0.1045\end{array}$ & 0.1127 & $\begin{array}{c}\mathrm{VS}_{7} \\
0.9379\end{array}$ & 0.9556 & $\begin{array}{c}\mathrm{VS}_{15} \\
0.9378\end{array}$ & 0.9239 & $\begin{array}{c}\mathrm{VS}_{23} \\
0.5967\end{array}$ & 0.6214 \\
\hline & B & 2.2811 & 2.2656 & $\begin{array}{c}\mathrm{NS}_{2} \\
0.1514\end{array}$ & 0.1565 & $\begin{array}{l}\mathrm{NS}_{10} \\
0.1231\end{array}$ & 0.121 & $\begin{array}{c}\mathrm{VS}_{8} \\
1.3022\end{array}$ & 1.2756 & $\begin{array}{c}\mathrm{VS}_{16} \\
0.6929\end{array}$ & 0.6939 & $\begin{array}{c}\mathrm{VS}_{24} \\
0.3197\end{array}$ & 0.333 \\
\hline & C & 2.1838 & 2.202 & $\begin{array}{c}\mathrm{NS}_{3} \\
0.1539\end{array}$ & 0.1572 & $\begin{array}{c}\mathrm{VS}_{1} \\
1.0328\end{array}$ & 0.9983 & $\begin{array}{c}\mathrm{VS}_{9} \\
0.3163\end{array}$ & 0.314 & $\begin{array}{c}\mathrm{VS}_{17} \\
0.3993\end{array}$ & 0.3876 & $\begin{array}{c}\mathrm{VS}_{25} \\
0.3354\end{array}$ & 0.38 \\
\hline & D & 1.663 & 1.658 & $\begin{array}{c}\mathrm{NS}_{4} \\
0.3469\end{array}$ & 0.295 & $\begin{array}{c}\mathrm{VS}_{2} \\
0.4797\end{array}$ & 0.4797 & $\begin{array}{c}\mathrm{VS}_{10} \\
0.2288\end{array}$ & 0.2423 & $\begin{array}{c}\mathrm{VS}_{18} \\
0.3799\end{array}$ & 0.3692 & $\begin{array}{c}\log _{1} \\
1.5194\end{array}$ & 1.5465 点 \\
\hline & E & 1.3006 & 1.4249 & $\begin{array}{c}\mathrm{NS}_{5} \\
0.1884\end{array}$ & 0.1808 & $\begin{array}{c}\mathrm{VS}_{3} \\
1.2475\end{array}$ & 1.0775 & $\begin{array}{c}\mathrm{VS}_{11} \\
0.2947\end{array}$ & 0.302 & $\begin{array}{c}\mathrm{VS}_{19} \\
0.6172\end{array}$ & 0.7502 & $\begin{array}{c}\log _{2} \\
0.8982\end{array}$ & 0.8505 兽: \\
\hline & $\mathrm{F}$ & 1.1254 & 1.0913 & $\begin{array}{c}\mathrm{NS}_{6} \\
0.1561\end{array}$ & 0.1514 & $\begin{array}{c}\mathrm{VS}_{4} \\
0.6022\end{array}$ & 0.5755 & $\begin{array}{c}\mathrm{VS}_{12} \\
0.7305\end{array}$ & 0.7569 & $\begin{array}{c}\mathrm{VS}_{20} \\
0.6655\end{array}$ & 0.6779 & $\begin{array}{c}\log _{3} \\
0.2591\end{array}$ & 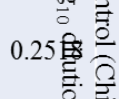 \\
\hline \multirow{2}{*}{ 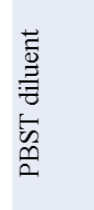 } & G & 0.0751 & 0.0886 & $\begin{array}{c}\mathrm{NS}_{7} \\
0.136\end{array}$ & 0.1275 & $\begin{array}{c}\mathrm{VS}_{5} \\
0.3877\end{array}$ & 0.7113 & $\begin{array}{c}\mathrm{VS}_{13} \\
0.8953\end{array}$ & 0.9325 & $\begin{array}{c}\mathrm{VS}_{21} \\
0.7939\end{array}$ & 0.7255 & $\begin{array}{l}\log _{4} \\
0.096\end{array}$ & 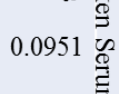 \\
\hline & $\mathrm{H}$ & 0.0674 & 0.0633 & $\begin{array}{c}\mathrm{NS}_{8} \\
0.1615\end{array}$ & 0.1588 & $\begin{array}{c}\mathrm{VS}_{6} \\
0.554\end{array}$ & 0.5981 & $\begin{array}{c}\mathrm{VS}_{14} \\
0.8873\end{array}$ & 1.0276 & $\begin{array}{c}\mathrm{VS}_{22} \\
0.7122\end{array}$ & 0.7446 & $\begin{array}{c}\log _{5} \\
0.0685\end{array}$ & 0.0697 \\
\hline
\end{tabular}

Fig.1 HI titres of vaccinated chicken sera samples, VS1-VS25 to show antibody anti-NDV levels

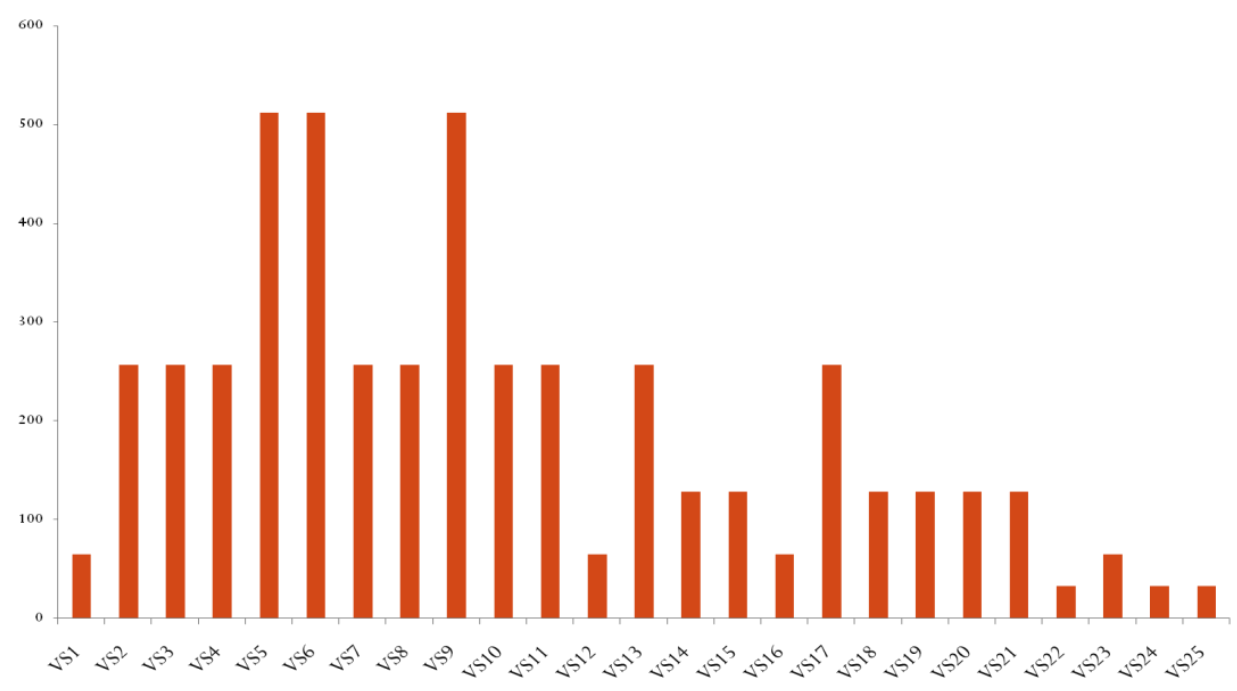


Fig.2 Microplate showing results of indirect ELISA. Intensity of brown colour in wells is indicative of relative antibody titres

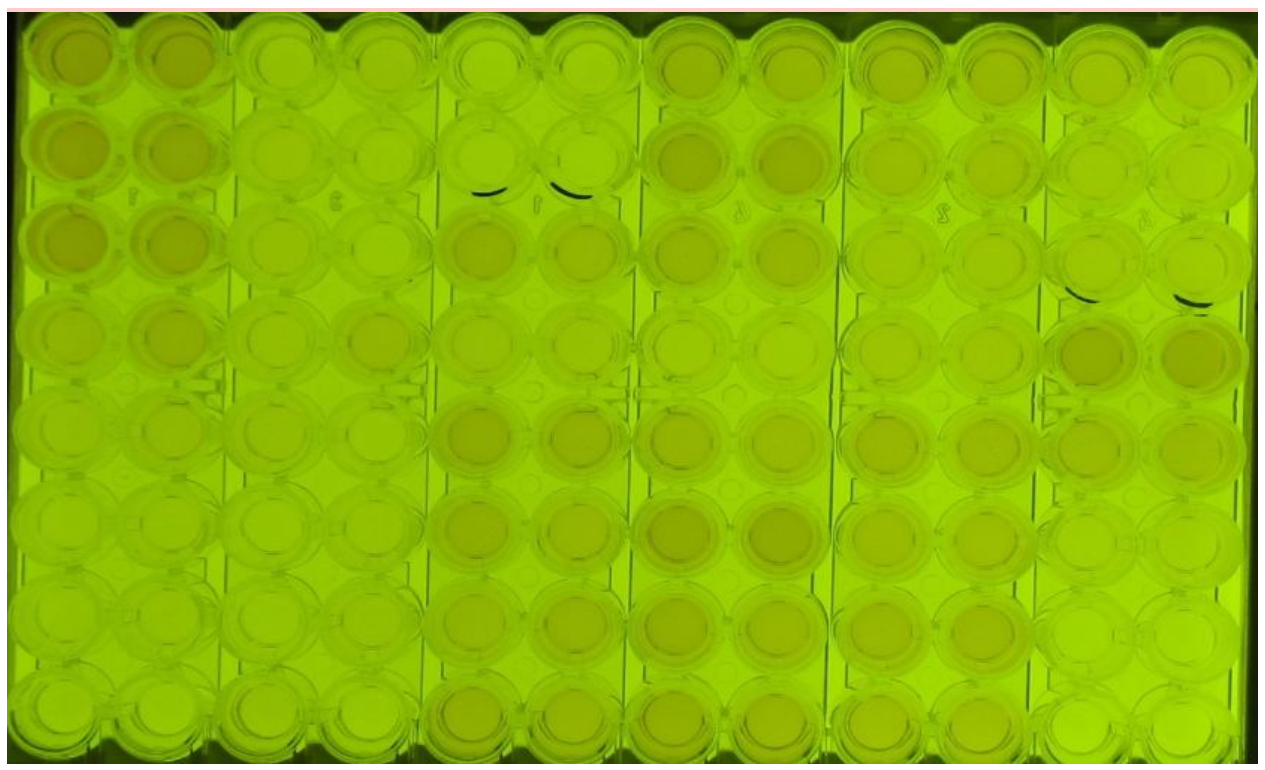

Fig.3 Anti-NDV antibody titres in vaccinated chicken sera samples measured by indirect ELISA

Anti-NDV Ab titres in vaccinated birds measuered by indirect ELISA

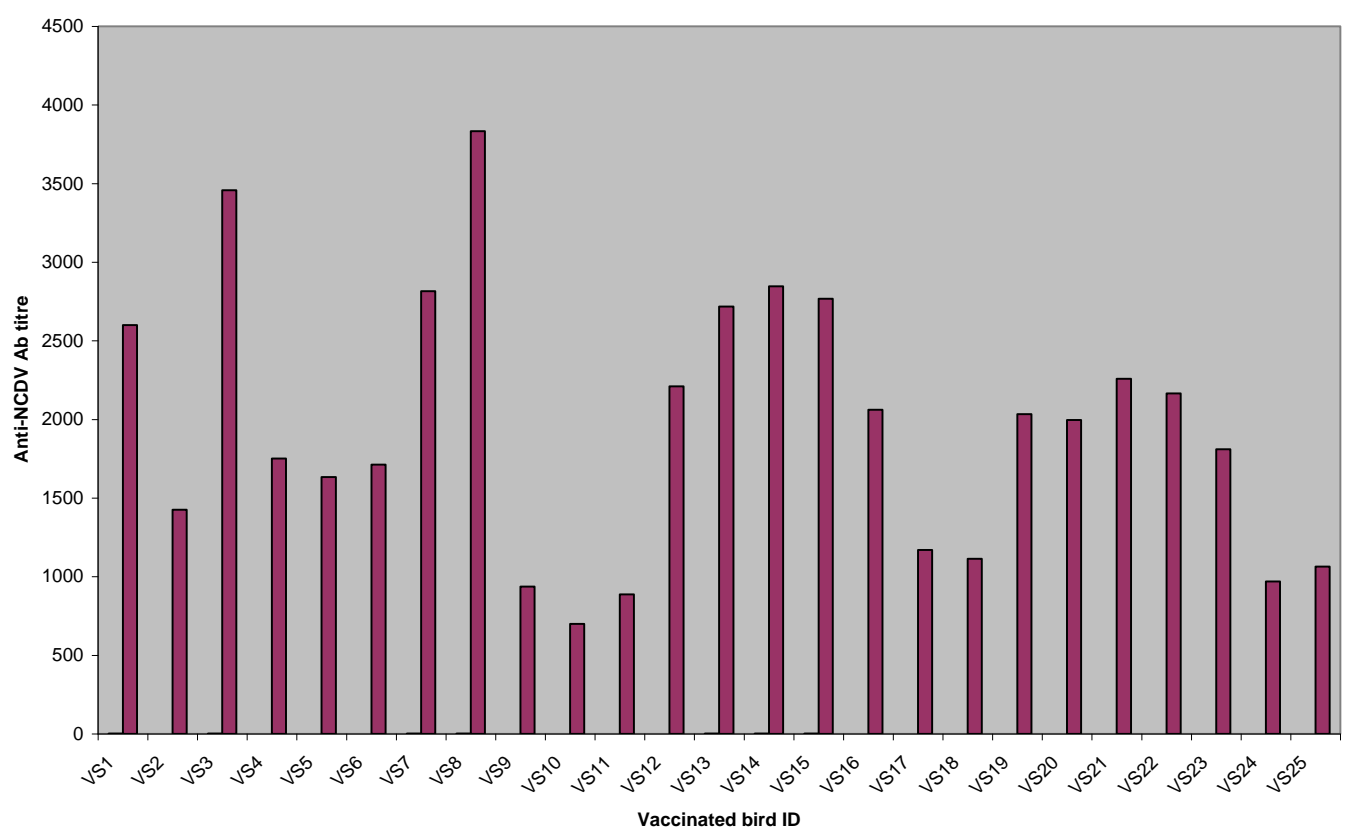


Table.4 Comparison of Ab titres in vaccinated chicken samples determined by ELISA and HI

\begin{tabular}{|c|c|c|}
\hline Sample ID & Ab titre ELISA & HI TITRE \\
\hline VS1 & 2600 & 64 \\
\hline VS2 & 1426 & 256 \\
\hline VS3 & 3457 & 256 \\
\hline VS4 & 1751 & 256 \\
\hline VS5 & 1634 & 512 \\
\hline VS6 & 1712 & 512 \\
\hline VS7 & 2815 & 256 \\
\hline VS8 & 3833 & 256 \\
\hline VS9 & 937 & 512 \\
\hline VS10 & 700 & 256 \\
\hline VS11 & 887 & 256 \\
\hline VS12 & 2211 & 64 \\
\hline VS13 & 2717 & 256 \\
\hline VS14 & 2847 & 128 \\
\hline VS15 & 2768 & 128 \\
\hline VS16 & 2062 & 64 \\
\hline VS17 & 1170 & 256 \\
\hline VS18 & 1114 & 128 \\
\hline VS19 & 2033 & 128 \\
\hline VS20 & 1997 & 128 \\
\hline VS21 & 2259 & 128 \\
\hline VS22 & 2166 & 32 \\
\hline VS23 & 1811 & 64 \\
\hline VS24 & 970 & 32 \\
\hline VS25 & 1064 & 32 \\
\hline
\end{tabular}

Anti-NDV antibody was also measured by indirect ELISA. The $\mathrm{Ab}$ titres in the vaccinated chicken sera samples were in the range of 700-3457. Inspection of indirect ELISA row data revealed 8 normal sera with A492 values $<0.2$ but 2 normal sera had $>0.2$, A492values which were higher than the expected absorbance for the negative serum control according to the optimized conditions for the ELISA. It seems that Abs levels measured by indirect ELISA in normal sera and vaccinated sera were more reliable than HI titres for these sera samples.

ELISA titre obtained in present study was higher than $\mathrm{HI}$ titre which has also been noticed by Roy et al., (2003). There are a variety of commercial ELISA kits available for detection of NDV-antibodies. HI test and ELISA might measure antibodies to different antigenic ELISA may detect antibodies to more than one antigen while the $\mathrm{HI}$ test is probably restricted to antibodies against $\mathrm{HN}$ protein only. So no correlation between HI and ELISA was found. In addition, ELISA titres were higher than $\mathrm{HI}$ titres because of the higher sensitivity of ELISA test than that of HI. No correlation between HI and ELISA titres could be established in the present study. Workers have presently reported variation in HI and ELISA titres, whereas some other have shown good correlation between HI and 
ELISA titres as reviewed by Alexender (2000). Makkay et al., (1999) could use antibody detection based differential ELISA for NDV infected or vaccinated chicken verses NDV-HN subunit vaccinated chickens using recombinant nucleocapsule protein NDV Hitchner B1 strain.

However, comparative study has been shown that ELISA test is reproducible and have high sensitivity and specificity. Although at present the HI test is most widely used for detecting Abs level in birds. Several poultry producer are using commercial ELISA kit to access post vaccination antibodies level.

\section{References}

Alexander, D.J. 2000. Newcastle Diseases in Ostriches (Struthio Camelus) a reviw. Avian pathology, 29: 95-100.

Alexander, D.J. 2001.Newcastle Disease. Gordon Memorial Lecture. British Poultry Science, 42: 5-22.

Beadrd, C.W and Wilkes, W.J. 1985. A comparison of Newcastle Disease haemagglutination tests results from diagnostic laboratories in southerneastern united states. Avian diseases. 29: 1048-1056.

Kaleta, E.F and Baldauf, C. 1988. Newcastle disease in free living and pet birds.In Newcastle disease, Ed. D.J. Alexander,
Boston, Kluwer Acad. Publication. pp: 197-246.

Lancaster, J.E.1976. A history of Newcastle disease with comments on its economic effects. World Poultry Sci J. 32: 167-175.

Law, B., Malone, M.D and Biddlecombe, R.A. 1996. Enzyme linked immunosorbent assay, development and optimization. In: Immunoassay: A practical guide, Law, B. (ed.), Tayler and Francis. pp: 127-147.

Makkay, A.M., Krell, P.J. and Nagy, E. 1999. Antibody detection - based differential ELISA for NDV infected in vaccinated chickens versus NDV RN-subunit vaccinated chicken. Veterinary Microbiology. 66: 209-222.

Roy, P., Vanugopal, A.T. and Dhillon A.S. 2003. Efficacy of two commercial Newcastle disease virus lentogenic vaccines against virulent Asiatic-type Newcastle disease viruses. Journal Applied Poultry Research. 12:169-173.

Sharma S.N. and Adlakha S. C. 2009. Text book of Veterinary Virology, Salasar Imaging Systems Press, Delhi.pp: 284309

Spradbrow, P.B. 1988. Geographical distribution. Newcastle Disease. Edited by: Alexander DJ., Boston: Kluwer Academic Publishers.pp.247-255.

\section{How to cite this article:}

Ojasvita, Himanshu sharma, Anupama Deora, Sanjay Kapoor, Ajit Singh, Satbir Sharma, Mahavir Singh, Pankaj Kumar and Rajendra Yadav. 2019. Comparative Study Between HI and Indirect ELISA Antibody Titres in Samples for NDV Virus in Poultry. Int.J.Curr.Microbiol.App.Sci. 8(11): 2450-2458. doi: https://doi.org/10.20546/ijcmas.2019.811.283 